\title{
Novel Platelet-agglutinating Protein from a Thrombotic Thrombocytopenic Purpura Plasma
}

Farooq A. Siddiqui and Eric C.-Y. Lian

Hemophilia and Thrombosis Center, Center for Blood Diseases, University of Miami School of Medicine and the Research and Medical Services, Veterans Administration Medical Center, Miami, Florida 33125

\begin{abstract}
A novel platelet-agglutinating protein (PAP) was purified $\sim 2,000$-fold from the plasma of a patient with thrombotic thrombocytopenic purpura (TTP) by ammonium sulfate fractionation, DEAE-Sephacel and concanavalin A-Sepharose chromatographies. On sodium dodecyl sulfate-polyacrylamide gel electrophoresis, with and without reduction, this preparation revealed a major protein band with a molecular weight of 37,000 , and a minor band with a molecular weight of 32,000-34,000. After elution from the gel, only the 37,000 -mol wt protein corresponding to the major band induced the platelet agglutination. When four normal plasmas and the recovery plasma from the same TTP patient were subjected to the similar purification steps, the 37,000-mol wt major band was absent. The ${ }^{125}$ I-PAP bound to the platelets in a concentration-dependent manner. The platelet agglutination induced by PAP was not inhibited by hirudin, heparin in the presence of antithrombin III, phenylmethylsulfonyl fluoride, apyrase, aspirin, or prostaglandin $I_{2}$. However, it was inhibited by IgG from normal adults and from the same TTP patient after recovery.

The anti-37,000-mol wt PAP antiserum prepared in the rabbit formed a single precipitin line against the highly purified PAP. Using this antiserum in the Western immunoblotting, the 37,000mol wt protein band was found in the three TTP plasmas, of which the platelet-agglutinating activity was inhibited by the anti-37,000-mol wt PAP IgG. The 37,000-mol wt immunoprecipitin band was absent in the plasmas obtained from another two TTP patients, two normal subjects, two patients with idiopathic thrombocytopenic purpura, and two patients with disseminated intravascular coagulation. These results suggest that the 37,000-mol wt PAP is present only in certain cases of TTP, and is likely to be responsible for the formation of platelet thrombi in the microcirculation.
\end{abstract}

\section{Introduction}

Thrombotic thrombocytopenic purpura (TTP) ${ }^{1}$ is characterized clinically by thrombocytopenia, microangiopathic hemolytic

Part of this work was presented at the National Meeting of the American Federation for Clinical Research, Washington, DC, 1984.

Address correspondence to Dr. Lian, VA Medical Center.

Received for publication 3 February 1985 and in revised form 24 June 1985.

1. Abbreviations used in this paper: Con A, concanavalin A; DIC, disseminated intravascular coagulation; ITP, idiopathic thrombocytopenic purpura; PAP, platelet-agglutinating protein; $\mathbf{P G I}_{2}$, prostaglandin $\mathbf{I}_{2}$; PMSF, phenylmethylsulfonyl fluoride; TTP, thrombotic thrombocytopenic purpura.

The Journal of Clinical Investigation, Inc.

Volume 76, October 1985, 1330-1337 anemia, fluctuating neurological signs, fever, and renal abnormalities $(1,2)$. The pathogenesis of this disorder is still not known. Deposition of microthrombi, consisting of platelets and fibrin, in the small vessels has been believed to be the primary cause of the clinical manifestations in $\operatorname{TTP}(3,4)$. Clinical studies have shown that some patients with TTP responded successfully to plasma infusion (5) or exchange (6). The agglutination of autologous and homologous platelets by TTP plasma has been demonstrated in this (7) and other laboratories (8-10). This agglutinating activity was not inhibited by hirudin, heparin in the presence of antithrombin III, diisopropyl fluorophosphate, apyrase, aspirin, or prostaglandin $\mathrm{I}_{2}\left(\mathrm{PGI}_{2}\right)(11)$. However, it was inhibited by human IgG or Fab fragments purified from the adult normal plasma (12).

In this communication, we report the purification of a 37,000-mol wt platelet-agglutinating protein (PAP) from the plasma of a TTP patient. This protein is specific for TTP because it is absent in the plasma obtained from the same patient after recovery, normal subjects and patients with disseminated intravascular coagulation (DIC), or idiopathic thrombocytopenic purpura (ITP). Some properties of this protein are described.

\section{Methods}

Materials. Aspirin, heparin, hirudin, apyrase, phenylmethylsulfonyl fluoride (PMSF), and globulin-free bovine serum albumin (BSA) were obtained from Sigma Chemical Co., St. Louis, MO. Antithrombin III was purchased from KabiVitrum Diagnostica, Stockholm, Sweden; human thrombin was from Ortho Diagnostics, Inc., Raritan, $\mathrm{NJ}$; aluminum hydroxide (Amphojel) was from Wyeth Laboratories, Philadelphia, PA; and human albumin (25\%) was from Armour Pharmaceutical Co., Kankakee, IL. Reagents used in sodium dodecyl sulfate (SDS)-polyacrylamide gel electrophoresis and low molecular weight protein markers (phosphorylase, BSA, ovalbumin, carbonic anhydrase, and soybean trypsin inhibitor), blot absorbent filter paper and the nitrocellulose membrane $(0.45 \mu \mathrm{m})$ were supplied by Bio-Rad Laboratories, Richmond, CA. DEAE Sephacel, Con A-Sepharose, and protein A-Sepharose CL-4B were obtained from Pharmacia Fine Chemicals, Uppsala, Sweden. Enzymobead reagent used in the iodination study was obtained from Bio-Rad Laboratories. $\mathrm{PGI}_{2}$ was a gift from Dr. J. Pike, Upjohn Co., Kalamazoo, MI. Carrier-free ${ }^{125} \mathrm{I}-\mathrm{Na}$ (specific activity $17.4 \mathrm{Ci} / \mathrm{mg}$ ), and ${ }^{14} \mathrm{C}$-labeled molecular weight marker proteins (phosphorylase, BSA, and ovalbumin) were purchased from New England Nuclear, Boston, MA. ${ }^{125}$ I-Protein A (specific activity $47.8 \mu \mathrm{Ci} / \mu \mathrm{g}$ ) was from ICN Radiochemicals, Irvine, CA. Freund's complete and incomplete adjuvants were from Difco Laboratories, Detroit, MI. All other chemicals were of analytical grade. The citrated plasma from normal subjects, patients with TTP, DIC, or ITP was prepared as described previously (12).

Preparation of washed platelet suspensions. Human platelets from normal subjects or a TTP patient after recovery were isolated from freshly drawn blood using an albumin density gradient method of Walsh et al. (13), with some modification, as described previously (11). The washed platelets were suspended in Tris-saline buffer, $\mathrm{pH} 7.4$, containing 133 $\mathrm{mM} \mathrm{NaCl}, 15 \mathrm{mM}$ Tris- $\mathrm{HCl}, 5 \mathrm{mM} \mathrm{KCl}$, and $1 \mathrm{mM} \mathrm{MgCl}_{2}$, and adjusted to a concentration of $7.5 \times 10^{8} / \mathrm{ml}$. 
Platelet agglutination. Platelet agglutination was measured in siliconized glass cuvettes with constant stirring in a Chrono-log aggregometer. The TTP plasma or various protein fraction collected during purification of PAP either diluted or undiluted with Tris-saline buffer in a total volume of $0.4 \mathrm{ml}$ was prewarmed at $37^{\circ} \mathrm{C}$ for $5 \mathrm{~min}$. To this, $0.1 \mathrm{ml}$ of washed platelet suspension containing $7.5 \times 10^{8}$ platelets $/ \mathrm{ml}$ were added. The decrease in optical density caused by the platelet agglutination was recorded. To confirm further that PAP causes agglutination, $0.1 \mathrm{ml}$ of platelet suspension was mixed with $0.1 \mathrm{ml}$ of Tris-saline buffer, $\mathrm{pH} 7.4$, containing $10 \mu \mathrm{g}$ PAP, and incubated at $37^{\circ} \mathrm{C}$ for $30 \mathrm{~min}$ without stirring. The incubation mixture was placed on a slide with coverslip and examined under phase microscope.

SDS-polyacrylamide gel electrophoresis. Polyacrylamide gel electrophoresis in the presence of SDS was performed according to the method of Laemmli (14), in 5\% stacking gels and in 10 or $12 \%$ separation polyacrylamide slab gels. The gels were stained with Coomassie Blue R-250. Molecular weight determinations were made by comparison to Bio-Rad Laboratories' reduced samples of phosphorylase b $(92,500)$, BSA $(66,000)$, ovalbumin $(45,000)$, carbonic anhydrase $(31,000)$, and soybean trypsin inhibitor $(21,500)$

Protein determination. Protein concentration was determined according to the method of Bradford (15) using BSA as the standard. For monitoring the column fractions, absorbance at $280 \mathrm{~nm}$ was used.

Purification of PAP. All operations were carried out at $4^{\circ} \mathrm{C}$ unless otherwise stated. The purification steps are summarized in Table $\mathrm{I}$. The PAP was purified from a TTP patient's plasma and was supplied by Dr. W. Rymer, Fort Lauderdale, FL. The citrated plasma was spun at 10,000 $g$ for $30 \mathrm{~min}$ before aluminum hydroxide adsorption.

Aluminum hydroxide adsorption. To $25 \mathrm{ml}$ of plasma, $1 / 30 \mathrm{vol}$ of aluminum hydroxide (undiluted) was added dropwise with stirring. The solution was incubated at $37^{\circ} \mathrm{C}$ for $10 \mathrm{~min}$. The supernatant, which contained the platelet-agglutinating activity, was recovered by centrifugation at $10,000 \mathrm{~g}$ for $30 \mathrm{~min}$.

Fractionation with ammonium sulfate. Aluminum hydroxide adsorbed plasma was brought to $50 \%$ ammonium sulfate saturation by the addition of saturated ammonium sulfate solution (pH 7.4). The suspension was stirred at $4^{\circ} \mathrm{C}$ for $30 \mathrm{~min}$, and the precipitate removed by centrifugation at $10,000 \mathrm{~g}$ for $30 \mathrm{~min}$. The precipitate was dissolved in 10 $\mathrm{ml}$ of $10 \mathrm{mM}$ Tris- $\mathrm{HCl}, \mathrm{pH} 7.4$, and dialyzed against 3 liters of the same buffer. After dialysis, the turbid solution was centrifuged at $10,000 \mathrm{~g}$ for $20 \mathrm{~min}$ and supernatant used for further purification.

DEAE Sephacel chromatography. The 0-50\% ammonium sulfate fraction was applied onto a DEAE Sephacel column $(2.3 \times 9.0 \mathrm{~cm})$ and equilibrated with $10 \mathrm{mM}$ Tris- $\mathrm{HCl}, \mathrm{pH}$ 7.4. The column was washed with the same buffer until absorbance at $280 \mathrm{~nm}$ became zero. It was then eluted with a $0-0.3 \mathrm{M} \mathrm{NaCl}$ linear gradient $(300 \mathrm{ml})$ in the equilibration buffer, and followed by stepwise elution with $0.3 \mathrm{M} \mathrm{NaCl}$ in the same buffer. The flow rate was $20 \mathrm{ml} / \mathrm{h}$, and $2.0-\mathrm{ml}$ fractions were collected and assayed for the platelet-agglutinating activity. The fractions in the third protein peak eluted by $0.3 \mathrm{M} \mathrm{NaCl}$ in $10 \mathrm{mM}$ Tris- $\mathrm{HCl}, \mathrm{pH}$ 7.4, which contained the maximum platelet-agglutinating activity, were pooled, and then were concentrated by negative pressure dialysis (DEAE Sephacel fraction III).

Concanavalin A (Con A)-Sepharose chromatography. The DEAE Sephacel fraction III was dialyzed against $20 \mathrm{mM}$ Tris- $\mathrm{HCl}$, pH 7.4, which contained $0.5 \mathrm{M} \mathrm{NaCl}, 1 \mathrm{mM} \mathrm{CaCl}$, and $1 \mathrm{mM} \mathrm{MnCl}_{2}$ (buffer A). The dialyzed solution was loaded onto a Con A-Sepharose column $(0.5 \times 9$ $\mathrm{cm}$ ) equilibrated with buffer $A$. The column was washed with buffer $A$ until the absorbance at $280 \mathrm{~nm}$ became zero. It was then eluted with a 40-ml linear gradient of $\alpha$-methyl-D-glucoside $(0-0.5 \mathrm{M})$ in buffer $\mathrm{A}$, and stepwise with $0.5 \mathrm{M}, 1.0 \mathrm{M} \alpha$-methyl-D-glucoside in buffer $\mathrm{A}$, and finally with $0.1 \mathrm{M}$ acetate buffer, $\mathrm{pH} 4.0$, containing $0.5 \mathrm{M} \mathrm{NaCl}$. Fractions of $0.5 \mathrm{ml}$ were collected at a flow rate of $10 \mathrm{ml} / \mathrm{h}$ and assayed for the platelet-agglutinating activity. Fractions in the 4th protein peak eluted with $0.1 \mathrm{M}$ acetate buffer, $\mathrm{pH} 4.0$, which contained $0.5 \mathrm{M} \mathrm{NaCl}$ and possessed the maximum activity, then were pooled, dialyzed against the Tris-saline buffer, $\mathrm{pH} 7.4$, and concentrated by negative pressure dialysis to a volume of $1.0 \mathrm{ml}$. The dialyzed protein (designated Con A fraction
IV) was stored at $-70^{\circ} \mathrm{C}$. Plasma from four normal donors and from the same TTP patient after recovery was processed through the same purification steps as described above.

Iodination of PAP and albumin. PAP (Con A fraction IV) was iodinated using lactoperoxidase technique, according to the procedure recommended by the manufacturer (Bio-Rad Laboratories), with some modification. Briefly, to $200 \mu \mathrm{l}$ of PAP $(40 \mu \mathrm{g})$ was added $150 \mu \mathrm{l}$ of 0.2 $\mathrm{M}$ potassium phosphate buffer, $\mathrm{pH} 7.2,100 \mu \mathrm{l}$ of Enzymobead reagent, $20 \mu \mathrm{l}$ of ${ }^{125} \mathrm{I}-\mathrm{Na}(2 \mathrm{mCi})$, and $100 \mu \mathrm{l}$ of $2 \% \beta$-D-glucose. The reagents were mixed and the iodination was allowed to proceed at room temperature for $25 \mathrm{~min}$. The reaction was quenched by centrifugation $(2,000$ $g$ for $10 \mathrm{~min}$ ) to remove the Enzymobead reagent from the reaction mixture. The supernatant was chromatographed on a Sephadex G-25 column $(1.0 \times 33 \mathrm{~cm})$ to remove the bound iodide from the labeled protein. Iodinated PAP (specific activity $50,000 \mathrm{cpm} / \mu \mathrm{g}$ ), was stored in $0.1 \%$ human serum albumin at $-70^{\circ} \mathrm{C}$. Serum albumin used as a control was iodinated in the same way as described above.

Binding of PAP to human platelets. Binding of ${ }^{125} \mathrm{I}$-labeled PAP to the washed platelets was performed at $37^{\circ} \mathrm{C} .0 .1-\mathrm{ml}$ aliquots of platelets $\left(7.5 \times 10^{8}\right.$ platelets $\left./ \mathrm{ml}\right)$ were incubated with varying amounts of iodinated PAP $(1.65-16.5 \mu \mathrm{g} / \mathrm{ml})$ in Tris-saline buffer, $\mathrm{pH} 7.4$, containing $0.1 \%$ human serum albumin, in a total volume of $0.2 \mathrm{ml}$. After a $30-\mathrm{min}$ incubation period the platelets were sedimented through a mixture of silicone oils (Hi-phenyl silicone-DC550 and methyl silicone oil-DC200, 4:1 (vol/vol), William F. Nye Inc., Fairhaven, MA) in an Eppendorf centrifuge at $12,000 \mathrm{~g}$ for $5 \mathrm{~min}$, according to the procedure of Bennett et al. (16). The supernatant and oil were aspirated and the platelet-bound ${ }^{125} \mathrm{I}$-radioactivity was counted. When $26-105 \mu \mathrm{g} / \mathrm{ml}$ of ${ }^{125} \mathrm{I}$-albumin (specific activity $49,500 \mathrm{cpm} / \mu \mathrm{g}$ ) was incubated with platelets as a control, the platelet-bound ${ }^{125} \mathrm{I}$-radioactivity was $<500 \mathrm{cpm} / 10^{8}$ platelets, i.e., there was essentially no binding of albumin to the platelets.

Effect of platelet inhibitors and adult human IgG from normal subject and TTP patient after recovery on PAP-induced platelet agglutination. Effect of certain inhibitors, such as hirudin $(1 \mathrm{U} / \mathrm{ml})$, heparin in the presence of antithrombin III ( $1 \mathrm{U} / \mathrm{ml}$ of each), PMSF $(1 \mathrm{mM})$, apyrase $(360 \mu \mathrm{g} / \mathrm{ml})$, aspirin $(200 \mu \mathrm{M})$, and $\mathrm{PGI}_{2}(60 \mu \mathrm{M})$ were studied on the PAP-induced platelet agglutination. The effect of adult human IgG from normal subjects and the TTP patient after recovery, purified as described previously (12), were also studied. Respective amounts of different inhibitors were preincubated at $37^{\circ} \mathrm{C}$ for $5 \mathrm{~min}$ with $10 \mu \mathrm{g}$ of PAP in Trissaline buffer, $\mathrm{pH} 7.4$, in a final volume of $0.4 \mathrm{ml}$. Platelet agglutination was recorded as described earlier, by the addition of $0.1 \mathrm{ml}$ washed platelet suspension $\left(7.5 \times 10^{8}\right.$ platelets $\left./ \mathrm{ml}\right)$. At the same concentration, hirudin and heparin in the presence of antithrombin III completely inhibited the thrombin $(1 \mathrm{U} / \mathrm{ml})$-induced platelet agglutination; apyrase, aspirin, and $\mathrm{PGI}_{2}$ inhibited $>80 \%$ of platelet agglutination induced by collagen at $3 \mu \mathrm{g} / \mathrm{ml}$ in the platelet-rich plasma, as described previously (11). Appropriate controls without inhibitor and blanks were always included.

Preparation of antiserum and IgG fraction against the PAP. The Con A fraction IV was subjected to a preparative SDS-polyacrylamide gel electrophoresis, and the 37,000-mol wt polypeptide was extracted from the gel using an ISCO concentrator (ISCO, Inc., Lincoln, NE). The extracted protein was free from other contaminating proteins, as analyzed by SDS-polyacrylamide gel electrophoresis. Approximately $30 \mu \mathrm{g}$ of the protein in $0.1 \mathrm{ml}$ was emulsified with an equal volume of Freund's complete adjuvant and injected into four subcutaneous sites in a New Zealand rabbit. Three similar injections were subsequently given in Freund's incomplete adjuvant after a 1-wk interval. The rabbit was bled from the ear vein before immunization, and twice weekly after the last injection. The serum was separated from the clot and stored at $-20^{\circ} \mathrm{C}$. For the purification of the IgG fraction, $10 \mathrm{ml}$ of the antiserum was brought to $50 \%$ ammonium sulfate saturation. The precipitate was recovered by centrifugation at $10,000 \mathrm{~g}$ for $30 \mathrm{~min}$, dissolved and dialyzed against 0.1 $M$ sodium phosphate, $\mathrm{pH} 7.4$, containing $0.02 \%$ sodium azide (buffer B). The dialyzed fraction was applied to a $1 \times 8-\mathrm{cm}$ column of protein A-Sepharose CL-4B equilibrated with buffer B. The column was washed with the same buffer until the absorbance became zero at $280 \mathrm{~nm}$. The bound $\mathrm{IgG}$ was eluted with $0.2 \mathrm{M}$ glycine-HCl buffer, $\mathrm{pH}$ 3.0. The eluted 
fractions with $>0.05 \mathrm{OD}$ at $280 \mathrm{~nm}$ were pooled and dialyzed against buffer B. The dialyzed IgG was concentrated by Centricon 10 microconcentrator (Amicon Corp., Danvers, MA) and stored at $-20^{\circ} \mathrm{C}$. The antibody concentration was estimated using an $\mathrm{E}_{280}^{1 \%}$ of 14.3.

Ouchterlony immunodiffusion. Immunodiffusion was carried out on glass slides coated with $1.2 \%$ agarose in $38 \mathrm{mM}$ Tris- $\mathrm{HCl}$ and $100 \mathrm{mM}$ glycine, $\mathrm{pH} 8.7$, with $0.02 \%$ sodium azide. All other conditions were the same as described previously (17).

Immunoblotting of PAP. The immunoblotting of polypeptides was carried out according to the method of Burnette (18) with some modifications. The electrophoresis of different protein fractions was performed on a $12 \%$ SDS-polyacrylamide slab gels according to the method of Laemmli (14). The polypeptides were transferred electrophoretically to nitrocellulose membrane. Immediately after transfer, the nitrocellulose membrane was soaked in $100 \mathrm{ml}$ of $5 \%$ BSA in $154 \mathrm{mM} \mathrm{NaCl}, 10 \mathrm{mM}$ Tris-HCl, pH 7.4 (Tris-saline), and incubated at $40^{\circ} \mathrm{C}$ for $1 \mathrm{~h}$ on a rocking platform. The membrane was then incubated with rabbit antiserum to PAP appropriately diluted with 5\% BSA in Tris-saline for $2 \mathrm{~h}$ at room temperature and $2 \mathrm{~h}$ at $4^{\circ} \mathrm{C}$. The membrane was then washed in 200 $\mathrm{ml}$ of Tris-saline containing $0.05 \% \mathrm{NP}-40$ for $20 \mathrm{~min}$ at room temperature. After washing six times, the membrane was immersed in 5\% BSA in fresh Tris-saline containing 4-7 $\times 10^{5} \mathrm{cpm}$ of ${ }^{125} \mathrm{I}$-protein $\mathrm{A} / \mathrm{ml}$. The binding of protein $\mathrm{A}$ was allowed to take place for $2 \mathrm{~h}$ with rocking at room temperature. The radioactive solution was aspirated and the nitrocellulose sheet was washed with $10 \mathrm{mM}$ Tris- $\mathrm{HCl}, \mathrm{pH} 7.4$, containing $0.5 \mathrm{M} \mathrm{NaCl}$ and $0.05 \% \mathrm{NP}-40$, for six times as described above. It was thoroughly dried with hair dryer. The sheet was exposed to Kodak $\mathrm{X}$-Omat AR film (Eastman Kodak Co., Rochester, NY) at $-70^{\circ} \mathrm{C}$ for $24 \mathrm{~h}$.

Effect of anti-PAP IgG fraction on the TTP plasma-induced platelet agglutination. A fixed volume of TTP plasma was incubated with $1 / 5 \mathrm{vol}$

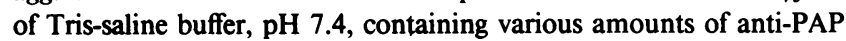
IgG, to make the final concentration of IgG to 20 or $200 \mu \mathrm{g} / \mathrm{ml}$ at $37^{\circ} \mathrm{C}$ for $2 \mathrm{~h}$. The incubation mixture was centrifuged at $48,200 \mathrm{~g}$ for $1 \mathrm{~h}$ at $4^{\circ} \mathrm{C}$. $0.4 \mathrm{ml}$ of the supernatant was removed and prewarmed at $37^{\circ} \mathrm{C}$ for $5 \mathrm{~min}$. To this, $0.1 \mathrm{ml}$ of prewarmed washed platelet suspension was added and platelet agglutination was recorded as described earlier. A control of TTP plasma without the anti-PAP IgG was always run under similar conditions.

\section{Results}

Purification of PAP. PAP was purified from the plasma of a patient with TTP. Table I shows the different steps involved in the purification. The DEAE Sephacel chromatography of 0-50\% $\left(\mathrm{NH}_{4}\right)_{2} \mathrm{SO}_{4}$ fraction is shown in Fig. 1. Two protein peaks with platelet-agglutinating activity were eluted from DEAE Sephacel column. The peak with the maximum agglutinating activity, eluted in $0.3 \mathrm{M} \mathrm{NaCl}$, was selected for further purification. The platelet-agglutinating protein recovered at this step had a specific activity of $20 \mathrm{U} / \mathrm{mg}$ of protein. Fractions under this peak were pooled, concentrated, and loaded onto a Con A-Sepharose affinity column. As shown in Fig. 2, three peaks with the plateletagglutinating activity were observed on a Con A-Sepharose chromatography. The first peak did not bind to Con A-Sepharose and appeared in the flow-through, and had some platelet-agglutinating activity, while the other two agglutinating activity peaks bound to the Con A column. The second activity peak eluted with a linear gradient of $\alpha$-methyl-D-glucoside had $\sim 20 \%$ agglutinating activity. Elution of the third activity peak was achieved with $0.1 \mathrm{M}$ acetate buffer, $\mathrm{pH} 4.0$, containing $0.5 \mathrm{M}$ $\mathrm{NaCl}$. This third activity peak (Con A fraction IV) had the maximum platelet-agglutinating activity; therefore, this was selected for detailed study. The platelet-agglutinating protein in the Con A fraction IV had a specific activity of $121.0 \mathrm{U} / \mathrm{mg}$ of protein, and was purified $\sim 2,000$-fold. The purification procedure as described above has been successfully reproduced eight times.

Attempts were made to see whether this agglutinating protein is also present in the normal and TTP plasma after recovery. Therefore, the normal plasma from fourth healthy donors, as well as the TTP recovery plasma from the same patient, were subjected to the same purification steps as described above. None of the plasma or fractions obtained during purification contained platelet-agglutinating activity.

Polyacrylamide gel electrophoretic studies. On a 0.1\% SDS$12 \%$ polyacrylamide slab gel electrophoresis with and without reduction, the Con A fraction IV obtained from TTP plasma showed a major protein band corresponding to a molecular weight of 37,000 , and a minor protein band with a molecular weight of 32,000-34,000. The 37,000-mol wt major band was completely absent in both the normal and recovery plasma, as judged by SDS-polyacrylamide gel electrophoresis (Fig. 3).

PAP-induced platelet agglutination. The PAP agglutinated the washed human platelets. As shown in Fig. 4, the magnitude of platelet agglutination was dependent upon the amounts of PAP (Con A fraction IV) used. After the proteins were eluted from the polyacrylamide gel, only the 37,000 -mol wt protein from the major band caused the platelets to agglutinate. The purified PAP not only caused the platelets of normal subjects to agglutinate, but also the platelets of the TTP patient after recovery, from whose plasma during disease this PAP was obtained (Fig. 5). The agglutination of platelets by PAP was further confirmed by observing the platelet clumps under phase microscope (Fig. 6).

Effect of inhibitors on the PAP-induced platelet agglutination. We have studied the effect of several inhibitors such as hirudin,

Table I. Purification of PAP from TTP Plasma

\begin{tabular}{|c|c|c|c|c|c|}
\hline Purification steps & Total protein & $\begin{array}{l}\text { Total agglutinating } \\
\text { activity }\end{array}$ & Specific activity & Yield & $\begin{array}{l}\text { Fold } \\
\text { purificationf }\end{array}$ \\
\hline & $m g$ & $U^{*}$ & $U / m g$ & $\% \ddagger$ & \\
\hline Plasma & $1,937.5$ & 125.0 & 0.065 & 100 & \\
\hline $\mathrm{Al}(\mathrm{OH})_{3}$ adsorbed fraction & $1,921.25$ & 106.0 & 0.055 & 100 & 1 \\
\hline $0-50 \%$ ammonium sulfate precipitate & 270.75 & 57.0 & 0.210 & 53.7 & 4 \\
\hline DEAE Sephacel column & 2.7 & 54.0 & 20.0 & 50.9 & 364 \\
\hline Con A-Sepharose column & 0.079 & 9.6 & 121.5 & 9.0 & 2,209 \\
\hline
\end{tabular}

${ }^{*} U$ is equivalent to the degree of platelet agglutination induced by $0.2 \mathrm{ml}$ of TTP plasma in the 0.5 -ml reaction mixture. $¥$ Percentage yield and the fold purification was calculated from the $\mathrm{Al}(\mathrm{OH})_{3}$ adsorbed plasma. 


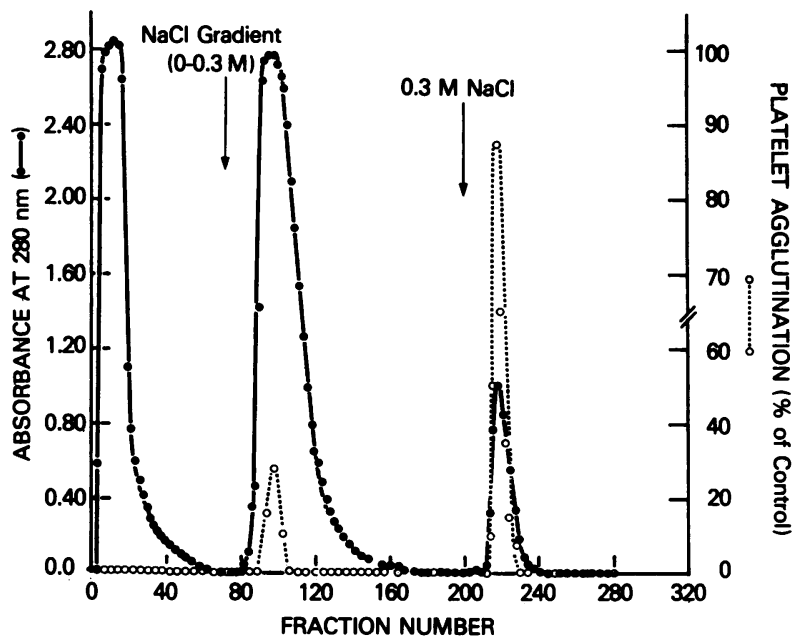

Figure 1. DEAE-Sephacel chromatography of 0-50\% $\left(\mathrm{NH}_{4}\right)_{2} \mathrm{SO}_{4}$ fraction. The ammonium sulfate fraction $(270.8 \mathrm{mg})$ after dialysis against $10 \mathrm{mM}$ Tris- $\mathrm{HCl}$ buffer, $\mathrm{pH} 7.4$, was loaded onto a DEAE-Sephacel column $(2.3 \times 9.0 \mathrm{~cm})$ preequilibrated with the same buffer. The column was first eluted with a $300-\mathrm{ml}$ linear gradient of $0-0.3 \mathrm{M} \mathrm{NaCl}$ in the same buffer, and then stepwise with $0.3 \mathrm{M} \mathrm{NaCl}$ (indicated by arrows). The flow rate was $10 \mathrm{ml} / \mathrm{h}$, and $2.0-\mathrm{ml}$ fractions were collected, dialyzed against the Tris-saline buffer, $\mathrm{pH} 7.4$, and assayed for platelet-agglutinating activity, which was expressed as percentage of control. The starting TTP plasma was used as the control, and the platelet agglutination induced by $0.2 \mathrm{ml}$ of TTP plasma was regarded as $100 \%$.

heparin in the presence of antithrombin III, PMSF, apyrase, aspirin, and $\mathbf{P G I}_{2}$ on the PAP-induced platelet agglutination. The results are summarized in Table II. None of the inhibitors

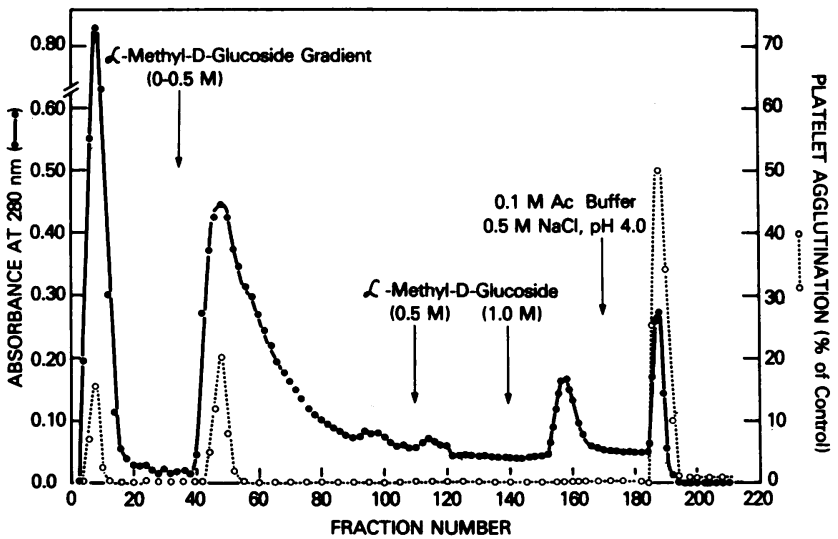

Figure 2. Con A-Sepharose chromatography of the PAP. DEAE Sephacel peak III was concentrated and dialyzed against $20 \mathrm{mM}$ Tris $\mathrm{HCl}$, pH 7.4, containing $0.5 \mathrm{M} \mathrm{NaCl}, 1 \mathrm{mM}$ each of $\mathrm{CaCl}_{2}$ and $\mathrm{MnCl}_{2}$ (buffer A). The dialyzed sample ( $2.7 \mathrm{mg}$ ) was loaded onto a Con ASepharose column $(0.5 \times 9 \mathrm{~cm})$ equilibrated with buffer $A$. The column was washed with the same buffer until absorbance at $280 \mathrm{~nm}$ was close to zero. It was eluted first with a 40-ml linear gradient of 0-0.5 $\mathrm{M} \alpha$-methyl-D-glucoside in buffer A, stepwise with $\theta .5,1.0 \mathrm{M}$ $\alpha$-methyl-D-glucoside, and finally with $0.1 \mathrm{M}$ acetate buffer, $\mathrm{pH} 4.0$, containing $0.5 \mathrm{M} \mathrm{NaCl}$ (indicated by arrows). Fractions of $0.5 \mathrm{ml}$ were collected at a flow rate of $5 \mathrm{ml} / \mathrm{h}$. The platelet-agglutinating activity was expressed with respect to control, as described in the legend of Figure 1. Ac, acetate.

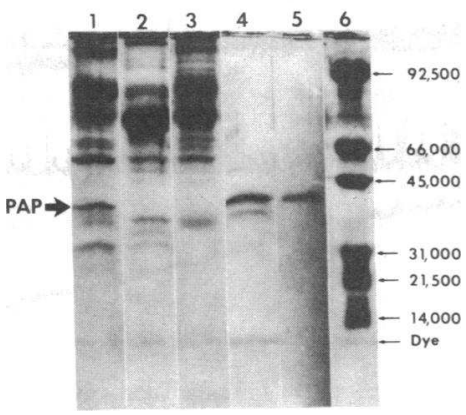

Figure 3. Electrophoretic patterns of the various protein fractions purified from normal, TTP disease, and TTP recovery plasma, and the purified PAP on a $12 \%$ SDS slab gel electrophoresis. Lanes $1-3$ show the gel electrophoresis of the DEAE Sephacel fraction III from TTP plasma in active disease (1), TTP plasma after recovery, (2), and nor-

mal plasma (3). Approximately $12 \mu \mathrm{g}$ of protein was applied in each lane. Presence of PAP band was indicated by a thick arrow. 4 shows the gel pattern of $7 \mu \mathrm{g}$ of Con A fraction IV. The two protein bands were extracted from the gel, and the platelet agglutination was checked. Only the 37,000 -mol wt protein agglutinated the platelets, and is shown in 5. Arrows indicate the molecular weight of the marker proteins: phosphorylase $b(92,500)$, BSA $(66,000)$, ovalbumin $(45,000)$, carbonic anhydrase $(31,000)$, soybean trypsin inhibitor $(21,500)$, and lysozyme $(14,400)$.

had any significant inhibitory effect on the PAP-induced platelet agglutination. However, the IgG from normal human adults as well as from the same TTP patient after recovery at a concentration of $500 \mu \mathrm{g} / \mathrm{ml}$ almost completely inhibited the agglutination.

Binding of PAP to human platelets. To study the binding of PAP with the platelets, platelet suspensions were incubated with various concentrations of ${ }^{125} \mathrm{I}$-labeled PAP (Con A fraction IV) for $30 \mathrm{~min}$ at $37^{\circ} \mathrm{C}$. The amount of ${ }^{125} \mathrm{I}-\mathrm{PAP}$ bound to the platelets was measured. As shown in Fig. 7, the binding of ${ }^{125}$ I-PAP to the platelets was concentration dependent. In the control experiment with ${ }^{125} \mathrm{I}-\mathrm{BSA}$, there was almost no binding, even at a 10-fold higher concentration.

Immunodiffusion and immunoblotting studies. The antiserum procured from rabbit after immunization with PAP formed a single precipitin line against highly purified PAP (Con A fraction IV) (not shown). Using this antiserum and Western blot technique, various fractions with platelet-agglutinating activity collected in the purification steps were examined for the presence of 37,000-mol wt PAP or its derivatives. As shown in Fig. 8, the $37,000-\mathrm{mol}$ wt band was absent in the 2 nd protein peak of DEAE Sephacel chromatography (lane 2), but present in the 1st (lane 3 ) and 2nd (lane 4) protein peaks of Con A-Sepharose chromatography. In addition to the 37,000-mol wt protein, the antiserum also reacted with smaller molecular weight $(\approx 18,000$ 33,000 ) polypeptides in the 2 nd peak of Con A-Sepharose chromatography. In some preparations, a 33,000-mol wt band was also seen in the first peak of same chromatography.

In order to determine whether 37,000-mol wt PAP is specific for TTP, DEAE Sephacel fractions III, prepared from the plasma of two normal subjects, five patients with TTP, two patients with DIC, and two patients with ITP, were used for the immunoblotting. It was found that the 37,000 -mol wt immunoprecipitin band was present in three out of five TTP patients, but absent in the normal subjects, patients with DIC or with ITP (Fig. 9). In two TTP patients, a low molecular weight polypeptide $\left(M_{\mathrm{r}}=29,000\right)$ was also noted on the autoradiograph (Fig. 9, lanes 4 and 5).

Effect of anti-PAP IgG on the TTP plasma-induced platelet agglutination. As shown in Table III, the anti-PAP IgG signifi- 


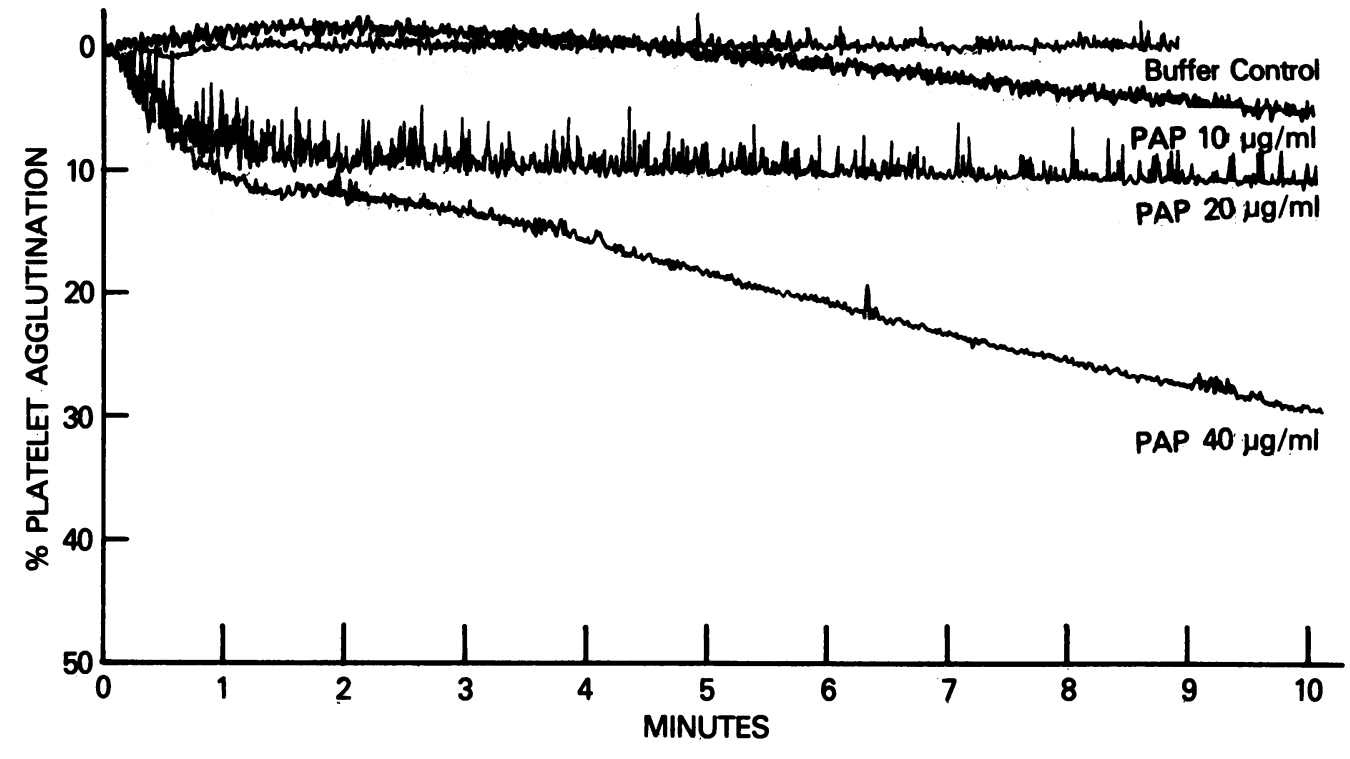

Figure 4. Agglutination of human platelets by various amounts of the highly purified PAP (Con A fraction IV). Variable amounts $(5-20 \mu \mathrm{g})$ of the purified protein in 0.4 $\mathrm{ml}$ of Tris-saline buffer, $\mathrm{pH}$ 7.4, was preincubated for 5 $\min$ at $37^{\circ} \mathrm{C}$, and then $0.1 \mathrm{ml}$ of washed platelet suspension $\left(7.5 \times 10^{8} / \mathrm{ml}\right)$ were added to the cell. In the control cell, the protein solution was replaced with an equal volume of Tris-saline buffer. cantly neutralized the platelet-agglutinating activity in the plasma of three out of five TTP patients. These three TTP plasmas, whose platelet-agglutinating activity was neutralized by anti-PAP IgG, were shown to contain the 37,000 -mol wt polypeptide on immunoblotting. The other two, whose platelet-agglutinating activity was not neutralized by anti-PAP IgG, did not possess the 37,000-mol wt polypeptide (Fig. 9, lanes 7 and 8).

\section{Discussion}

Thrombotic thrombocytopenic purpura is characterized pathologically by the deposition of platelet thrombi in the capillaries and arterioles $(3,4)$. The agglutination of platelets by TTP plasma had earlier been demonstrated in this laboratory (7). In the pres-

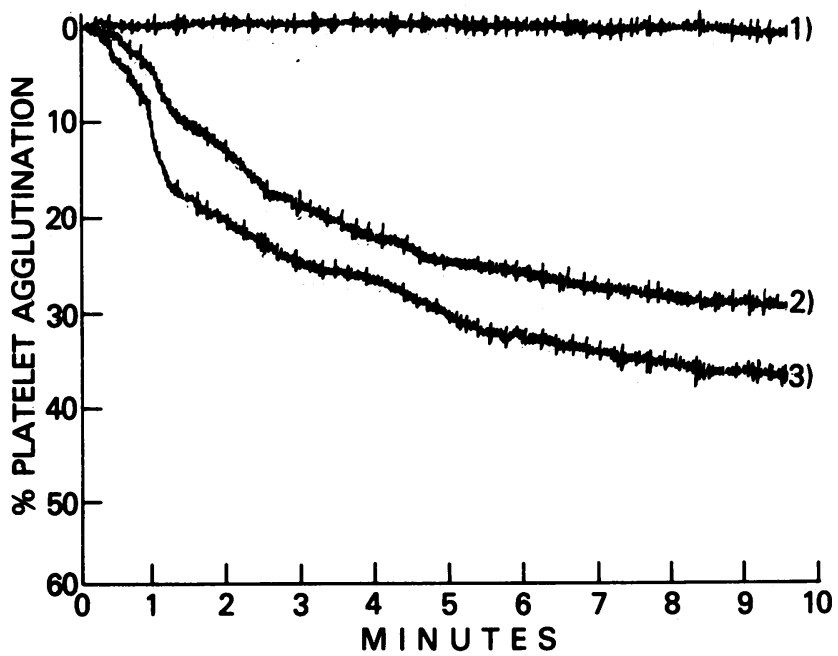

Figure 5. Agglutination by PAP of washed platelets from a normal subject and the same TTP patient after recovery, from whose plasma during disease the P.AP was purified. $0.4 \mathrm{ml}$ of Tris-saline containing $30 \mu \mathrm{g} / \mathrm{ml}$ of PAP was incubated for $5 \mathrm{~min}$ at $37^{\circ} \mathrm{C}$ and added to 0.1 $\mathrm{ml}$ of washed platelet suspension $\left(7.5 \times 10^{8} / \mathrm{ml}\right)$ from a normal subject (line 2) or the TTP patient (line 3). Line 1 represents the control study in which Tris-saline buffer without PAP was added to either normal or TTP platelet suspension. ent study, we have succeeded in highly purifying a platelet-agglutinating protein from a TTP patient plasma by ammonium sulfate fractionation, DEAE Sephacel, and Con A-Sepharose chromatographies. Its tight binding to DEAE Sephacel and Con A-Sepharose suggests that the PAP is likely a highly negatively charged glycoprotein. On SDS-polyacrylamide gel electrophoresis, the Con A fraction IV containing the maximum plateletagglutinating activity showed two protein bands: a major protein band with a molecular weight of 37,000 and a minor band with a molecular weight of 32,000-34,000. Only the 37,000-mol wt protein agglutinated the platelet after extraction from the gel. The behavior of the $37,000-\mathrm{mol}$ wt protein with and without reduction was the same on SDS-polyacrylamide gel, suggesting that it is composed of a single polypeptide.

The highly purified platelet-agglutinating protein not only agglutinated the platelets from normal subjects but also those from the same TTP patient after recovery. This suggests that PAP is not an isoantibody or its derivative. The magnitude of

Table II. Effect of Platelet Inhibitors and Human IgG on PAP-induced Platelet Agglutination

\begin{tabular}{lllc}
\hline & Final & $\begin{array}{l}\text { Platelet } \\
\text { agglutination* } \\
\text { with respect } \\
\text { to control }\end{array}$ & $\begin{array}{c}\text { Inhibi- } \\
\text { tion }\end{array}$ \\
\hline Inhibitor & concentration & $\%$ & $\%$ \\
\hline & - & 100 & 0 \\
PAP (no inhibitor) & $1 \mathrm{U} / \mathrm{ml}$ & 99 & 1 \\
Hirudin & $1 \mathrm{U} / \mathrm{ml}$ each & 84 & 16 \\
Heparin + antithrombin III & $1 \mathrm{mM}$ & 100 & 0 \\
PMSF & $360 \mu \mathrm{g} / \mathrm{ml}$ & 100 & 0 \\
Apyrase & $200 \mu \mathrm{M}$ & 100 & 0 \\
Aspirin & $60 \mu \mathrm{M}$ & 100 & 0 \\
PGI & $500 \mu \mathrm{g} / \mathrm{ml}$ & 0 & 100 \\
IgG from normal adult & & & 86 \\
IgG from the same TTP & $500 \mu \mathrm{g} / \mathrm{ml}$ & 14 & \\
\multicolumn{1}{c}{ patient after recovery } & & & \\
\hline
\end{tabular}

* Platelet agglutination induced by $20 \mu \mathrm{g} / \mathrm{ml}$ of PAP without inhibitor was used as a control (100\%). 


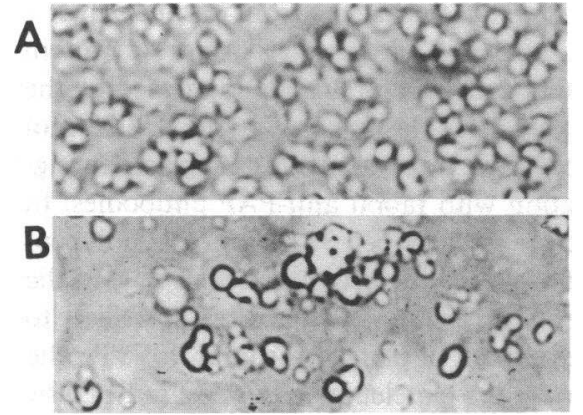

Figure 6. Photographs of platelets agglutinated by purified PAP under phase microscope. $\times 600$. $A$ represents the control in the absence of PAP. $B$ represents the agglutinated platelet clumps in the presence of $\mathrm{PAP}$ at $50 \mu \mathrm{g} / \mathrm{ml}$.

platelet agglutination was dose dependent. We have studied its binding to the platelets. The binding of ${ }^{125}$ I-PAP to platelets is concentration dependent and specific, because ${ }^{125} \mathrm{I}-\mathrm{BSA}$ at a 10 fold higher concentration failed to show any significant binding to platelets. This suggests that the binding of PAP to platelets may be a prerequisite for PAP-induced platelet agglutination.

We have studied the effect of different inhibitors on PAPinduced platelet agglutination. Known thrombin inhibitors, such as hirudin (19), heparin in the presence of antithrombin III (20), and PMSF, blocked the thrombin-induced, but not PAP-induced platelet agglutination. This suggests that the highly purifid PAP is not thrombin or contaminated with thrombin. Elimination of extracellular ADP by apyrase inhibits the platelet aggregation by epinephrine and collagen (21). The PAP-induced platelet agglutination was not affected by apyrase. This suggests that the release of ADP is not essential in the PAP-induced platelet agglutination. Aspirin, a known inhibitor of prostaglandin biosyn-

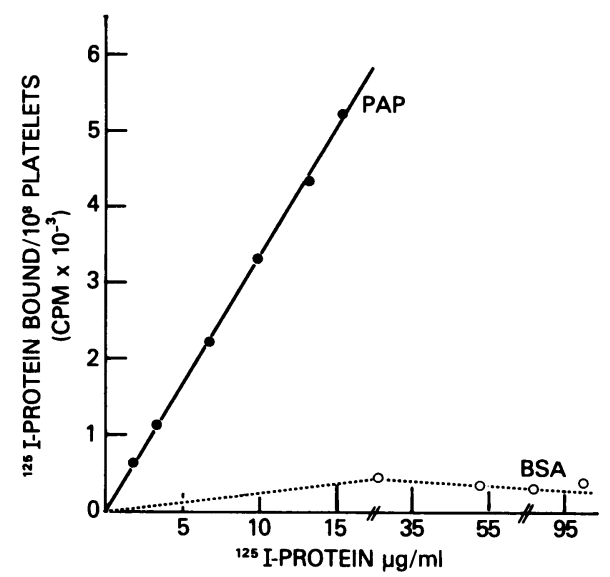

Figure 7. Binding of ${ }^{125} \mathrm{I}$-PAP to washed human platelets. $0.1-\mathrm{ml}$ aliquots of platelet suspension $\left(7.5 \times 10^{8} / \mathrm{ml}\right)$ in Tris-saline buffer, $\mathrm{pH}$ 7.4 , containing $0.1 \%$ of human serum albumin, were incubated for 30 min at $37^{\circ} \mathrm{C}$ with various concentrations of iodinated PAP in a total volume of $0.2 \mathrm{ml}$. The platelets were centrifuged through silicone oil cushion, and the amounts of ${ }^{125} \mathrm{I}-\mathrm{PAP}$ bound to platelets $\left(\mathrm{cpm} / 10^{8}\right.$ platelets) was determined (๑). Each point is the mean of duplicate determinations. To show the specificity of this reaction, binding of ${ }^{125} \mathrm{I}$ BSA at a 10-fold higher concentration was studied in a similar manner (O).

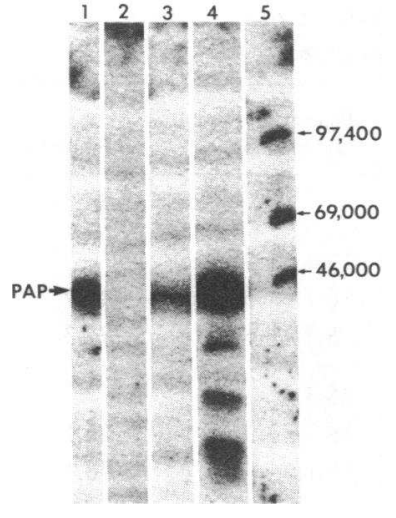

Figure 8. Immunoblotting of the purified PAP and various protein fractions obtained during purification with the PAP antiserum. Approximately $15-20 \mu \mathrm{g}$ of protein from each peak and $0.37 \mu \mathrm{g}$ of the purified PAP were subjected to SDS-gel electrophoresis in a $12 \%$ polyacrylamide slab gel, and the fractionated proteins were transferred to nitrocellulose membrane. The blot was allowed to react with rabbit antiserum against the purified PAP. The formed immune precipitates on the blot were illuminated with ${ }^{125} \mathrm{I}$-protein $\mathrm{A}$ fol-

lowed by autoradiography. Lane 1 , purified PAP; 2 , 2nd peak of DEAE-Sephacel chromatography; and 3 and 4, 1st and 2nd protein peaks of Con A-Sepharose chromatography, respectively. Position of the PAP band was indicated with a thick arrow. 5 shows the ${ }^{14} \mathrm{C}$-molecular weight marker proteins: phosphorylase $b(97,400)$, BSA $(69,000)$, and ovalbumin $(46,000)$.

thesis (22, 23), did not inhibit PAP-induced platelet agglutination. This indicates that PAP-induced agglutination is independent of prostaglandin biosynthesis in platelets. $\mathrm{PGI}_{2}$, which has been shown to elevate platelet cyclic AMP levels (24) and inhibit platelet aggregation and secretion by ADP, thrombin, and subendothelial surfaces (25), failed to inhibit the platelet agglutination caused by PAP. These findings are consistent with our previous observations that thrombin inhibitors (7), nonsteroidal anti-inflammatory drugs, and $\mathrm{PGI}_{2}(11)$ had no inhibitory effect on TTP plasma-induced platelet agglutination. Recently it was demonstrated that a pentapeptide extracted from Microcystitis aeruginosa caused the microcircular thrombi in the lung that were composed of platelets. Heparin, aspirin, or $\mathrm{PGI}_{2}$ was also shown to be incapable of preventing the thrombi formation (26).

We have previously reported the inhibition of TTP plasmainduced platelet agglutination by human IgG from normal adults as well as from TTP patients after recovery, but not by human IgG from normal infants or TTP patients with active disease

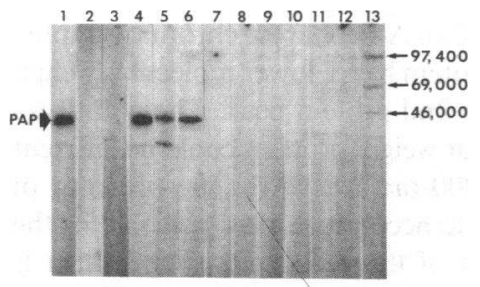

Figure 9. Immunoblotting of the DEAE-Sephacel fraction III prepared from the plasma of normal subjects and patients with TTP, DIC and ITP, and purified PAP with anti-PAP antiserum. About $20-24 \mu \mathrm{g}$ protein in the DEAE-Sephacel purified fraction III from various plasmas, and $0.15 \mu \mathrm{g}$ of purified PAP and ${ }^{14} \mathrm{C}$-molecular weight marker proteins ( $16 \mathrm{nCi}$ each), were subjected to $12 \%$ SDS-polyacrylamide gel electrophoresis. Proteins were transferred to nitrocellulose membrane and blotted with specific PAP antiserum, followed by reaction with ${ }^{125} \mathrm{I}$-protein $\mathrm{A}$ and autoradiography. Lane 1 , purified PAP; 2 and 3, plasmas from two normal donors; 4-8, plasmas from five different TTP patients; 9 and 10, plasmas from two DIC patients; and 11 and 12 , two plasmas from two ITP patients. Presence of PAP band was indicated by a thick arrow. 13 shows the ${ }^{14} \mathrm{C}$-molecular weight marker proteins: phosphorylase b $(97,400)$, BSA $(69,000)$, and ovalbumin $(46,000)$. 
Table III. Effect of Rabbit Anti-PAP IgG on the TTP Plasma-induced Platelet Agglutination

\begin{tabular}{lcll}
\hline TTP plasma & Anti-PAP IgG & $\begin{array}{l}\text { Platelet } \\
\text { agglutination }\end{array}$ & Inhibition \\
\hline \multirow{4}{*}{$\mu$} & $\mu g / m l$ & $\%$ & $\%$ \\
& 0 & 19.1 & \\
& 20 & 16.7 & 12.7 \\
2 & 200 & 5.3 & 72.3 \\
& 0 & 25.3 & \\
& 20 & 18.7 & 26.1 \\
3 & 200 & 11.1 & 56.1 \\
& 0 & 11.7 & \\
& 20 & 7.4 & 36.8 \\
4 & 200 & 6.5 & 44.4 \\
& 0 & 10.5 & \\
& 20 & 23.4 & 0 \\
5 & 200 & 9.7 & 8 \\
& 0 & 15.2 & 0 \\
& 20 & 19.1 & 0 \\
& 200 & 16.7 & \\
& & &
\end{tabular}

A mixture of $0.5 \mathrm{ml}$ TTP plasma and $0.1 \mathrm{ml}$ Tris-saline buffer, $\mathrm{pH}$ 7.4, containing various amounts of anti-PAP IgG, was incubated at $37^{\circ} \mathrm{C}$ for $2 \mathrm{~h}$. After centrifugation at $48,200 \mathrm{~g}$ for $1 \mathrm{~h}$, the plateletagglutinating activity of the supernatant was determined.

(12). Therefore, the effect of IgG from normal adults and the same TTP patient after recovery on the PAP-induced agglutination was studied. We found that $\mathrm{IgG}$ at a concentration of $500 \mu \mathrm{g} / \mathrm{ml}$ almost completely inhibited the platelet agglutination induced by PAP. The possible mechanism of IgG inhibition on the TTP plasma-induced platelet agglutination has been discussed previously (12).

To evaluate whether the platelet-agglutinating activity in the other protein peaks eluted from the DEAE-Sephacel and Con A-Sepharose columns was due to the $37,000-\mathrm{mol}$ wt PAP or its derivatives, Western blot method was used. Using rabbit antiPAP antiserum in the immunoblotting, it was shown that the 37,000 -mol wt polypeptide band was absent in the 2 nd protein peak of DEAE Sephacel chromatography but present in both 1 st and 2nd protein peaks of Con A-Sepharose chromatography. Other than 37,000-mol wt protein band, lower molecular weight bands were also noted in the 2 nd protein peak. These antigenically identical lower molecular weight proteins could be different forms or derivatives of 37,000-mol wt PAP. The presence of 37,000-mol wt PAP is likely to account at least partially for the platelet-agglutinating activity of these two protein peaks. It is not clear why the 37,000 -mol wt PAP has different affinity to Con A. It could be due to the different amounts or kinds of carbohydrates on PAP, or its complex formation with other proteins. These remain to be clarified.

In contrast to the TTP plasma obtained during active disease, when plasma from four healthy normal donors and from the same TTP patient after recovery were processed in exactly the same manner as for the active TTP plasma, we noticed the 37,000-mol wt protein band on polyacrylamide gel was completely absent. Furthermore, immunoblotting demonstrated that the $37,000-\mathrm{mol} \mathrm{wt}$ protein was presently only in three out of five TTP plasma, but absent in the plasma from normal subjects and patients with DIC or ITP. That the $37,000-\mathrm{mol}$ wt protein is a platelet-agglutinating protein was further confirmed by the observation that the three TTP plasmas having the 37,000-mol $w$ protein band reduced their platelet-agglutinating activity significantly after incubation with rabbit anti-PAP antibodies. In conclusion, the heretofore undescribed 37,000-mol wt polypeptide possessing platelet-agglutinating activity, present only in the plasma of certain cases of TTP during active disease, is likely to contribute to the development of platelet thrombi in TTP. The substances responsible for the platelet agglutination induced by various TTP plasmas appear to be heterogeneous, as suspected before (12).

\section{Acknowledgments}

This work was supported by National Institutes of Health grant 27007, the Veterans Administration, and by the American Heart Association of Greater Miami.

\section{References}

1. Moschcowitz, E. 1925. An acute fibrile pleiochromic anemia with hyaline thrombosis of the terminal arterioles and capillaries: an undescribed disease. Arch. Intern. Med. 36:89-93.

2. Amorosi, E. L., and J. E. Ultmann. 1966. Thrombotic thrombocytopenic purpura: report of 16 cases and view of literature. Medicine (Baltimore). 45:139-159.

3. Kwaan, H. C. 1979. The pathogenesis of thrombotic thrombocytopenic purpura. Semin. Thromb. Hemostasis. 3:184-198.

4. Myers, T. J., C. J. Wakem, E. D. Ball, and S. J. Tremont. 1980. Thrombotic thrombocytopenic purpura: combined treatment with plasmapheresis and antiplatelet agents. Ann. Intern. Med. 92:149-155.

5. Byrnes, J. J., and E. C-Y. Lian. 1979. Recent therapeutic advances in thrombotic thrombocytopenic purpura. Semin. Thromb. Hemostasis. 5:199-215.

6. Bukowski, R. M., J. W. King, and J. S. Hewlett. 1977. Plasmapheresis in the treatment of thrombotic thrombocytopenic purpura. Blood. 50:413-417.

7. Lian, E. C.-Y., D. R. Harkness, J. J. Byrnes, H. Wallach, and R. Nunez. 1979. The presence of a platelet aggregating factor in the plasma of patients with thrombotic thrombocytopenic purpura and its inhibition by normal plasma. Blood. 53:333-338.

8. Ansell, J., N. I. Slepchuk, and L. Pechet. 1979. Thrombotic thrombocytopenic purpura. Blood. 54:959-960.

9. Brandt, J. T., M. S. Kennedy, and D. A. Senhauser. 1979. Platelet aggregating factor in thrombotic thrombocytopenic purpura. Lancet. II: 463-464.

10. Burns, E. R., and D. Zucker-Franklin. 1982. Pathologic effects of plasma from patients with thrombotic thrombocytopenic purpura on platelets and cultured vascular endothelial cells. Blood. 60:1030-1037.

11. Lian, E. C.-Y., and N. Savaraj. 1981. Effects of platelet inhibitors on the platelet aggregation induced by plasma from patients with thrombotic thrombocytopenic purpura. Blood. 58:354-359.

12. Lian, E. C.-Y., P. Mui, F. A. Siddiqui, A. Y. Chiu, and L. L. S. Chiu. 1984. Inhibition of platelet aggregating activity in thrombotic thrombocytopenic purpura plasma by normal adult immunoglobulin $\mathbf{G}$. J. Clin. Invest. 73:548-555.

13. Walsh, P. N., D. C. B. Mills, and J. G. White. 1977. Metabolism and function of human platelets washed by albumin density gradient separation. Br. J. Haematol. 36:287-296.

14. Laemmli, U. K. 1970. Cleavage of structural proteins during the assembly of the head of bacteriophage T4. Nature (Lond.) 227:680-685.

15. Bradford, M. 1976. A rapid and sensitive method for the quantitation of microgram quantities of protein utilizing the principle of protein dye binding. Anal. Biochem. 72:248-254. 
16. Bennett, J. S., J. A. Hoxie, S. F. Leitman, G. Vilaire, and D. B. Cines. 1983. Inhibition of fibrinogen binding to stimulated human platelets by a monoclonal antibody. Proc. Natl. Acad. Sci. USA. 80:24172421.

17. Siddiqui, F. A., and B. I. S. Srivastava. 1978. Terminal deoxyribonucleotidyl transferase from acute lymphoblastic leukemia cells and production of antisera. Biochim. Biophys. Acta. 517:150-157.

18. Burnette, W. N. 1981. Western Blotting: electrophoretic transfer of proteins from sodium dodecyl sulfate polyacrylamide gels to unmodified nitrocellulose and radiographic detection with antibody and radioiodinated protein A. Anal. Biochem. 112:195-203.

19. Markwardt, F., and P. Walsmann. 1958. Die Reaktion Zeischen hirudin und thrombin. Hoppe-Seyler's Z. Physiol. Chem. 312:85-98.

20. Rosenberg, R. D., and P. S. Damus. 1973. The purification and mechanism of action of human antithrombin-heparin cofactor. J. Biol. Chem. 248:6490-6505.

21. Kinlough-Rathbone, R. L., M. A. Packham, H. J. Reimers, J. P.
Cazenave, and J. F. Mustard. 1977. Mechanisms of platelet shape change, aggregation, and release induced by collagen, thrombin or A23187. $J$. Lab. Clin. Med. 99:707-719.

22. Hamberg, M., J. Svesson, and B. Samuelsson. 1974. Prostaglandin endoperoxides. A new concept concerning the mode of action and release of prostaglandin. Proc. Natl. Acad. Sci. USA. 71:3824-3828.

23. McIntyre, B. A., and K. B. Phillip. 1977. Effect of three nonsteroidal anti-inflammatory agents on platelet function and prostaglandin synthesis in vivo. Thromb. Res. 12:67-77.

24. Gorman, R. R., S. Bunting, and O. V. Miller. 1977. Modulation of human platelet adenylate cyclase by prostacyclin (PGX). Prostaglandins. 12:377-388.

25. Wautier, J. L., and J. P. Caen. 1979. Pharmacology of platelet suppressive agents. Semin. Thromb. Hemostasis. 5:293-315.

26. Slatkin, D. N., R. D. Stoner, W. H. Adkams, J. H. Kycia, and H. W. Siegelman. 1983. A typical pulmonary thrombosis caused by a toxic cyanobacterial peptide. Science (Wash. DC). 220:1383-1385. 